\title{
CZY TO WSTYD WSPOMINAĆ? KILKA WSTĘPNYCH PORUSZEŃ TEMATU
}

\author{
Wacław LEWANDOWSKI (Toruń)
}

W przedmowie do wydanej w 1959 roku monografii twórczości Stefana Grabińskiego Artur Hutnikiewicz pisał:

Badania naukowe nad literaturą polską ujawniają od dawna niepokojącą jednostronność. Oto koncentrują się one $\mathrm{z}$ uporczywą wyłącznością na nielicznych wybranych i uprzywilejowanych zjawiskach i osobistościach twórczych, ze względów artystycznych czy nawet pozaartystycznych niekiedy uznanych za pierwszoplanowe i jakoby szczególnie ważne i doniosłe. Wszystko inne przedstawia się jak rozległa, zagadkowa, nie tknięta jeszcze stopą odkrywcy „,ziemia nieznana”. Tę pozostałą resztę, ilościowo przecie imponująca, a jakościowo dotąd wciąż jeszcze nie zweryfikowaną i nie osądzona, załatwia się zazwyczaj sumaryczną, ryczałtową ocena, pozbawioną jakichkolwiek [...] umotywowań. Powstaje w rezultacie obraz rzeczywistości literackiej w założeniu zwichnięty i nieomal do gruntu zafałszowany ${ }^{1}$.

Przypominam te słowa w przekonaniu, że można je dziś bez żadnych korekt i retuszu odnieść do stanu krajowych badań nad literaturą Drugiej Emigracji, o czym świadczą m.in. dzieje badawczej refleksji nad emigracyjnym pisarstwem wspomnieniowym. Nie ma kłopotu z wyliczeniem tekstów historycznoliterackich, poświęconych wyłącz-

\footnotetext{
${ }^{1}$ A. Hutnikiewicz, Twórczość literacka Stefana Grabińskiego (1887-1936), Toruń 1959, s. 5.
} 
nie temu nurtowi emigracyjnego piśmiennictwa - w ciągu kilkudziesięciu już lat rozwoju badań nad historią literatury polskiej powstałej na obczyźnie od II wojny światowej ogłoszono zaledwie jeden szkic na ten temat ${ }^{2}$. Inni badacze zbywali ów - jak przyjdzie wykazać - rozległy obszar literackiego dorobku emigrantów ubocznym napomknieniem i zryczałtowaną, arbitralną oceną o niejawnej motywacji. Wymownym przykładem takiego postępowania jest opinia Rafała Habielskiego:

[...] memuarystyka stała się, w dużym stopniu za sprawą nostalgii za dawnością, polem kreacji potrzebnego emigracji wizerunku przeszłości. [...] Swoiste postrzeganie historii było jedną z cech wyróżniających myślenie emigracji niezłomnej. [...] W oczywisty sposób prowadziło to do polonocentryzmu [...]. Ta cecha memuarystyki londyńskiej jest o tyle charakterystyczna, że stanowi w zasadzie zaprzeczenie deklaracji o konieczności kontaktu z kulturą europejską (zachodnia) składanych po wojnie ${ }^{3}$.

Co ciekawsze, większość autorów-emigrantów, odnotowujących emigracyjną falę wspomnień, zdaje się podzielać pogląd Marii Danilewicz Zielińskiej, że była to nawała tyleż gwałtowna co krótkotrwała, silnie zaznaczająca swą obecność przede wszystkim w pierwszym okresie emigracyjnego bytowania. W Szkicach... Danilewiczowa pisała:

Przymus spisywania wspomnień dotknął emigrację na długo przed wystapieniem analogicznego zjawiska w kraju. Pamiętniki „domowe” miały przekazywać obrazy „panatadeuszowe”, ewokować utracone raje lub na chłodno inwentaryzować realia przeszłości. [...] W następnym rzucie pojawiły się, jeszcze w okresie wojny, wspomnienia oderwane od współczesności, ujęte w formę opowiadań, z autorem w roli narratora. [...] Sama pisałam takie obrazki $\mathrm{z}$ tłem kujawskim [...]. Inną pobudką do kreślenia wspomnień była także potrzeba umiejscowienia autora i jego antenatów w ramach dawnej egzystencji [...]. Ta faza należy już do przeszłości, ale w okresie jej rozkwitu na łamach „Wiadomości” i pomniejszych pism i pisemek narodził się termin „wspominkarstwo" w sensie zdecydowanie pejoratywnym, jako wyraz sprzeciwu młodych przeciw jękliwym rozpamiętywaniom przez starsze generacje utraconego raju. Sprzeciw ten nie odnosił się do okupacji, zsyłek sowieckich i większości wspomnień ze szlaków wojennych $^{4}$.

Z kręgu pejoratywnie ocenianego „wspominkarstwa” Danilewiczowa wyłączała więc relacje o zdarzeniach historycznych i polskich losach, o których w kraju pisać i mówić nie było wolno. W tym zakresie obowiązek świadczenia nie budził odruchu sprzeciwu - był przez emigrantów świadomie przyjmowany, stając się częścią składową emigracyjnej służby Polsce. Dodatkowej zachęty do utrwalania prawdy historycznej we wspomnieniach dostarczały napływające z kraju publikacje wspomnieniowe, które w przejrzyście aluzyjny sposób ukazywały, że ich autorzy w trosce o własne bezpieczeństwo, a nawet życie, musieli poddać się samocenzurze. Doskonałym przykładem takiego ,sygnału” jest wywód Jana Nepomucena Millera, niedwuznacznie odnoszący do sprawy i do tragicznego losu żydowskich działaczy - Wiktora Altera i Henryka Ehrlicha, zgładzonych przez NKWD.

${ }^{2}$ Zob.: J. Olejniczak, Proza „wspominkarska”, [w:] Literatura emigracyjna 1939-1989, t. 2, red. tenże, Katowice 1996, s. 126-136. Nie wspominam tu, rzecz jasna, o pracach na temat świadectw GUŁagu, których autorzy, co oczywiste, sieggali do pisarstwa wspomnieniowego; zob. np.: I. Sariusz-Skąpska, Polscy świadkowie GUŁagu. Literatura tagrowa 1939-1989, Kraków 2002.

${ }^{3}$ R. Habielski, Życie spoteczne i kulturalne emigracji, Warszawa 1999, s. 162-163.

${ }^{4}$ M. Danilewicz Zielińska, Szkice o literaturze emigracyjnej pótwiecza 1939-1989, Wrocław 1999, s. 295-296. 
Gdybym pisał pamiętnik (czego nie uczynię ze względu na małoduszną troskę o własne bezpieczeństwo...), zacząłbym zapewne od wspomnienia, że kto wie, czy nie jako jeden z pierwszych w roku 1933 w „Nowym Piśmie”, redagowanym przez Wiktora Altera [...] podjąłem sprawę jednolitego frontu na skrzydle kultury ${ }^{5}$.

Świadomość ograniczeń, jakim poddani są ci, którzy w kraju pozostali, była, zapewne, przyczyną tego, że z czasem emigracyjne oficyny wydawnicze ogłosiły pewną ilość książek wspomnieniowych spisanych w PRL i - z autorskiego założenia - nie przeznaczonych do druku w państwowych wydawnictwach. Do roku 1976 publikacji tego rodzaju materiałów wydawcy emigracyjni podejmowali się zazwyczaj po śmierci autora $^{6}$. Byłoby celowym, co odnotowuję na marginesie, ustalenie liczby takich wydań, jako należących w pewnej mierze do zasobu emigracyjnej twórczości wspomnieniowej.

Tezie o przejściowym charakterze przypływu „,wspominkarstwa” dobitnie zaprzeczył w roku 1978 Eugeniusz Romiszewski, dziennikarz RWE i autor diariusza, którym posiłkował się Jan Nowak-Jeziorański, spisując swoje radiowe wspomnienia, w ogłoszonym w II tomie londyńskiego „Pamiętnika Literackiego” opracowaniu pt. Wzmożona fala wspomnień $w$ literaturze emigracyjnej 1961-1976. Do artykułu Romiszewski dołączył bibliografię książek pamiętnikarskich za lata 1961-1977². Nawet jeśli uwzględnić, że kilka z notowanych tam tytułów to wznowienia książek wydanych wcześniej, trudno patrząc na to zestawienie nie przyznać, że teza Danilewiczowej niewiele miała wspólnego z rzeczywistością życia literackiego emigracji. Łatwo, natomiast, potwierdzić intuicję Romiszewskiego, który przewidział, że „fala wspomnień" będzie się nasilać w okresie, by tak rzec „późno emigracyjnym”. Wystarczy przyjrzeć się zawartości najpopularniejszej na emigracji serii wydawniczej — „kieszonkowcom Sakowskiego". Juliusz Sakowski, kierujący wydawnictwem Polskiej Fundacji Kulturalnej, obmyślił cykl serii wydawniczych (po pięć tytułów każda) książek w formacie kieszonkowym. Każdą ,piątkę” czytelnicy mogli subskrybować, zyskując tą drogą znaczny rabat. Seria pierwsza ukazała się w 1963 roku, ostatnia, 28., w 1980. Łacznie wydano 140 tytułów. 49 spośród nich to pozycje wspomnieniowe, co stanowi aż 35\% całości, a warto zaznaczyć, że nie wliczam w to tzw. wspomnień fabularyzowanych. Jeżeli założyć, że proporcja ta odzwierciedla stosunki ilościowe w całej emigracyjnej produkcji literackiej, trzeba by uznać, że piśmiennictwo wspomnieniowe stanowiło więcej niż trzecią część literackiego dorobku emigracji. W tym świetle brak badań nad tą częścią piśmiennictwa Drugiej Emigracji wydaje się żenującym zaniedbaniem, zwłaszcza w zestawieniu z sądami tych historyków literatury, którzy twierdzą, że obszar emigracyjny jest już polem badawczym wyeksploatowanym.

Romiszewski zajął się okresem od roku 1961, zapewne w przekonaniu, że całość literatury emigracyjnej do roku 1960 włącznie została zinwentaryzowana w dwutomowej Literaturze polskiej na obczyźnie, zredagowanej przez Tymona Terleckiego, choć zaznaczył, że w opracowaniu tym brak osobnego rozdziału poświęconego literaturze

${ }^{5}$ J. N. Miller, Bez kropki nad „,”, Warszawa 1964, s. 209.

${ }^{6}$ Typowym przykładem są wspomnienia Jana Hoppego (zm. w 1969 r.), spisane w celu ,utrwalenia procesu walk o uspołecznienie państwa”; zob.: J. Hoppe, Wspomnienia, przyczynki, refleksje, Londyn 1972.

${ }^{7}$ Zob.: E. Romiszewski, Wzmożona fala wspomnień w literaturze emigracyjnej 1961-1976, Pamiętnik Literacki (Londyn) 1978 t. II, s. 48-81 oraz: tenże, Emigracyjna literatura pamiętnikarska. Ksiażki wydane w latach 1961-1977, Pamiętnik Literacki (Londyn) 1978 t. II, s. 81-86. Wymowne jest, że opracowania Romiszewskiego krajowi badacze literatury emigracyjnej właściwie nie dostrzegli. Wyjątkiem jest tu Rafał Habielski; zob.: tenże, Humanistyka polska poza krajem. Rekonesans, Nauka 2005 nr 2, s. 69. 
wspomnień, co jest godną dostrzeżenia wadą tej syntezy. Istotnie, w dziele tym tytuły utworów wspomnieniowych pojawiają się przy różnych okazjach, samo zaś zjawisko fali wspomnień skwitowane jest następującą uwagą Marii Danilewiczowej:

Do niedawna kierowano pod adresem literatury emigracyjnej zarzut tkwienia we wspominkach i przesadnej pasji pamiętnikarskiej. Dziś, gdy Kraj produkuje pozycje z tego działu na setki a nie przysłowiowe kopy, można przejść nad tym zarzutem w milczeniu. [...] Zarzut nadmiaru wspomnień jest nonsensem; mówić raczej można o zaniedbaniu skreślenia pamiętników przez wielu naocznych świadków i uczestników ważnych wydarzeń historycznych, po których — jak to w czasach wojennych — niewiele pozostało śladów w archiwach oficjalnych ${ }^{8}$.

Wolno chyba sądzić, że refleksja Danilewiczowej nad emigracyjnym „wspominkarstwem" motywowana była względami ideowymi. Danilewiczowa, po prostu, przez dziesięciolecia niezmiennie reagowała na tezę propagandy krajowej, w myśl której pisarze-emigranci mieli być lokatorami „śmietnika historii”, skazanymi na jałowe rozpamiętywanie dawnego życia i utraconego stanu posiadania. Aby ów zarzut oddalić, badaczka lekceważyła ilość, a częściowo także powagę i znaczenie „wspominkarskich” pozycji literackich, uznając dorobek wspomnieniowy emigracji — w kontekście wspomnianej propagandowej tezy — za nieco wstydliwy. Być może, kierując się tym samym dążeniem, to ona właśnie przekonała Terleckiego do takiego układu materiału w syntetycznym opracowaniu literatury emigracyjnej, który literatury wspomnieniowej osobno nie eksponuje. Sam bowiem Terlecki wagi tego rodzaju pisarstwa nigdy nie kwestionował, przeciwnie - przypisywał mu zadania kulturowo najistotniejsze. W 1948 roku pisał:

Przeciw literaturze wspomnień podnosiły się wśród nas głosy neurasteniczne krytycyzmu. A przecież wspominanie, wiązanie czasów z czasami, cała funkcja pamięci jest równie naturalna i ważna, jak przedłużanie gatunku, jak wiązanie pokoleń z pokoleniami. Są to dwa plany, biologiczny i duchowy, tej samej sprawy znikomej, jak wszystko ludzkie, i wzniosłej i tajemniczej, i wspaniałej, zdawać się może bezcelowej, a jednak jedynej, dla której się żyje i dla której warto jest umierać ${ }^{9}$.

Nie można wykluczyć, że na decyzjach Danilewiczowej zaważyły też przestrogi Józefa Wittlina, który w głośnym eseju Blaski i nędze wygnania mówił o zdominowaniu intelektu przez funkcję pamięci jako o jednym z największych zagrożeń dla twórczej produktywności pisarza-emigranta ${ }^{10}$. Być może, swoją wagę i wpływ miała tu też przemowa Gombrowicza z Dziennika, którą Józef Olejniczak uznał za „najostrzejszy atak" na zjawisko emigracyjnej literatury wspomnień ${ }^{11}$. Gombrowicz w ,Mowie do narodu”, rzekomo wygłoszonej „na bankiecie w gościnnym domu pp. X, u schyłku A.D. 1953”, grzmiał przeciwko „mazgajstwu wspomnień”, mówiąc m.in.:

Gdy święta nadejdą, lubicie podlewać łzami klomb wspomnień i wzdychać rzewnie do utraconych miejsc rodzinnych. Nie bądźcie śmieszni, ani ckliwi! Nauczcie się dźwigać własne przeznaczenie. Przestańcie opiewać mdławo piękności Grójca, Piotrkowa lub Biłgoraja. [...] Cóż z tego, że nie przebywacie w Grodnie, Kutnie lub Jedlińsku? Czy kiedykolwiek człowiek przebywał gdzie indziej, niż w sobie? [...] Nieprawda, że Grójec jest czymś więcej niż przeraźliwą i prowincjonalną dziura, w której ongiś

\footnotetext{
${ }^{8}$ M. Danilewiczowa, Poglad ogólny na literaturę emigracyjna, [w:] Literatura polska na obczyźnie 1940-1960, t. II, red. T. Terlecki, Londyn 1965, s. 641.

${ }_{9}^{9}$ T. Terlecki, Ignacy Baliński, [w:] tegoż, Spotkania ze swoimi, Wrocław 1999, s. 95.

${ }^{10}$ Zob.: J. Wittlin, Orfeusz w piekle XX wieku, Kraków 2000, s. 153-168.

${ }^{11}$ Zob.: J. Olejniczak, Proza ,wspominkarska”, s. 130.
} 
biedowała wasza szara egzystencja. Niw, to kłamstwo: Radom nigdy nie był poematem, nawet o wschodzie słońca! Nie są cudowne i niezapomniane tamtejsze kwiaty - a nędza, brud, choroby, nuda i krzywda osaczały was i wówczas, jak psy wyjące głuchych polskich wsi o zmroku. [...] Dziś natomiast nie mieszkacie już w Polsce, ale za to Polska silniej w was zamieszkała — ta Polska, którą określić należy jako najgłębszą ludzkość waszą, urobioną pracą pokolen ${ }^{12}$.

Mamy tu jednak do czynienia z zadawnionym nieporozumieniem interpretacyjnym. Gombrowicz nie tyle drwi i odcina się od wspomnieniowego piśmiennictwa emigracyjnego i samej emigracji, ile próbuje sięgnąć po „rząd dusz”, stać się duchowym przewodnikiem emigrantów. Jak Mickiewicz, gdy w Księgach... przywracał polistopadowym wychodźcom poczucie godności i użyteczności wołając, że nie są tułaczami, lecz pielgrzymami, tak Gombrowicz woła: „Jesteście u siebie, choćbyście znajdowali się w Argentynie lub w Kanadzie, ponieważ ojczyzna nie jest miejscem na mapie, ale żywą istnością człowieka". Wpisane w dzieło Gombrowicza dążenie do przywództwa duchowego nad emigracją czeka zresztą na pełne odczytanie i omówienie. Ma, natomiast, rację J. Olejniczak, gdy zauważa, że Gombrowicz niejako skodyfikował „prozę wspominkarską" jako pełnoprawny nurt literatury emigracyjnej, gdy przygotował dla RWE cykl gawęd Wspomnienia polskie, które ,wpisując się w ten nurt polskiego piśmiennictwa, jednocześnie prowadzą z nim swoisty, przesycony autoironią, dyskurs" ${ }^{\text {"13 }}$.

Pierwszym, najistotniejszym zadaniem badawczym, jakie stawia przed nami ten nurt emigracyjnego piśmiennictwa, jest rozpoznanie i uporządkowanie zagadnień genologicznych. Co właściwie — w sensie gatunkowym — do „wspominkarstwa” należy? Czy genologiczny zasób emigracyjnej literatury wspomnień jest różny od analogicznego zasobu literatury okresu PRL? - To byłyby najbardziej podstawowe pytania, od dawna czekające na próbę odpowiedzi. Jak pisał J. Olejniczak, M. Danilewicz Zielińska zaliczyła do ,literatury wspominkarskiej” wszystkie realizacje literatury wspomnieniowej, w których pojawił się motyw utraconej ojczyzny, pomijając w ten sposób aspekt genologii dzieła literackiego ${ }^{14}$. O zbadanie pod katem genologii emigracyjnego „wspominkarstwa” upominał się już Józef Bujnowski ${ }^{15}$. Zwracał uwagę na ciążenie materiału wspomnieniowego w kierunku literackiej fikcji, powodujące intrygującą badawczo produktywność tego pisarstwa w zakresie tworzenia form i gatunków pogranicznych. Niestety, apel Bujnowskiego mimo przypomnień ${ }^{16}$ pozostał dotąd bez odzewu.

Trzeba też rzetelnie zastanowić się nad znaczeniem i wagą tego nurtu piśmiennictwa emigracji. W 1981 roku Artur Hutnikiewicz w referacie Historyczne i ideowe przestanki ostatniej emigracji polskiej orzekał, że jednym z najtrwalszych emigracyjnych dzieł jest „tworząca się tam od półwiecza literatura artystyczna”, dodawał jednak, że bujnie się rozwijająca literatura pamiętnikarska „w swej zdecydowanej większości stanowi [...] bezcenne niekiedy dopełnienie historycznych dokumentów naszego czasu" ${ }^{\prime 17}$. Wydaje się, że ów walor dokumentacyjny nie jest przecie jedynym. Jeśli zastanowić się nad statusem literatury wspomnień w tradycji polskiej, stwierdzić wypadnie, że pojęcie literatury narodowej ma u nas — z ograniczonymi wyjątkami — zakres sztucznie zawężony niemal wyłącznie do produkcji o prymarnych dążnościach arty-

\footnotetext{
${ }^{12}$ W. Gombrowicz, Dziennik 1953-1956, Kraków 1997, s. 95-96.

${ }^{13}$ J. Olejniczak, Proza ,wspominkarska”, s. 130.

${ }^{14}$ Zob.: tamże, s. 129.

${ }^{15}$ Zob.: J. Bujnowski, Esej wspominkarsko-obyczajowy i autobiograficzny, [w:] Literatura polska na obczyźnie 1940-1960, t. I, red. T. Terlecki, Londyn 1964, zwł. s. 231.

${ }^{16}$ Zob.: W. Lewandowski, W sprawie „, bilansu Emigracji”, Kresy $1997 \mathrm{nr} 3(31)$, s. 157-161.

${ }^{17}$ Zob.: A. Hutnikiewicz, To co najważniejsze. Trzy eseje o Polsce, Bydgoszcz 1996, s. 69-70.
} 
stycznych, przynajmniej gdy chodzi o literaturę nowszą, poromantyczną. Inaczej rzecz się ma w innych krajach, gdzie nikomu nie przychodzi do głowy wyłączać wybitnych produkcji pamiętnikarskich z kręgu literatury wysokiej. Przykład noblisty w dziedzinie literatury - Winstona Churchilla jako autora pamiętników jest, myślę, wystarczająco wymowny.

Osobnym zagadnieniem jest ustalenie, jak szeroki był krąg autorski pisarzy wspomnień. W sposób niejako naturalny przyznajemy ,prawo” spisywania wspomnień osobom znacznym, odgrywającym w jakimś momencie dziejowym rolę historyczną, np. politykom czy wysokim rangą dowódcom wojskowym. Warto byłoby stwierdzić, jak daleki postęp miała na emigracji, by tak powiedzieć, demokratyzacja memuarystyki. Wydaje się, że znaczny, skoro daje się napotkać wydania pamiętników tzw. szarych ludzi, uzasadniane przez wydawców względami filozoficznymi, czy nawet teologicznymi. Tak, np., w przedsłowiu do wydanej w Kanadzie autobiografii Stanisława Kawczyńskiego, Stanisław Wcisło przypominał:

Już Pascal pisał że wszyscy ludzie z racji swej ludzkiej kondycji są na tym samym poziomie; a jeśli niektórzy są wyżsi od nas to dlatego, że głowę noszą wyżej; ale stopy ich są równie nisko co nasze. [...] Nasz autor, legitymując się w ten sposób, powinien uniknąć zarzutu krytyków [...], że jest „niepowołany”, że „nie wnosi nic nowego”, że powtarza to co już raz było opisane ,wytrawniejszym piórem”, że tkwi w przeszłości; tym więcej, iż los wcale mu wstrząsów nie poskapił ${ }^{18}$.

Jeżeli badania potwierdziłyby tezę o szerokiej (i z czasem postępującej) ,demokratyzacji” wspominania, piśmiennictwo wspomnieniowe okazałoby się najważniejszym materiałem do badań świadomości i kultury (nie tylko literackiej) emigracyjnej społeczności. Przy okazji warto zastanowić się nad dawną refleksją Tymona Terleckiego, który właśnie wspomnieniom ludzi przekonanych o własnej nieznaczności przypisywał największe walory literackie i etyczne.

Wspomnienia o Warszawie [Ignacego] Balińskiego [...] nie zrodziły się z poczucia własnej wartości, ani z chęci świadczenia o wydarzeniach przeżytych, choć były wśród nich osobliwe i najosobliwsze w dziejach naszego narodu. Wspomnienia Balińskiego liczą się do kategorii jakby najbardziej samowystarczalnej, bezinteresownej i — gdyby się chciało ustalać skalę wartości - do kategorii może najwyższej. Wywodzą się one z samego mistycznego poczucia wagi życia, jego dobra, i jego urody, zmienności i bogactwa $^{19}$.

Interesująca będzie też wewnętrzna dynamika rozwoju tego obszaru emigracyjnego piśmiennictwa. Trzeba — wobec skali zjawiska — żywić podejrzenie, że przynajmniej niektóre utwory pamiętnikarskie wchodziły w relacje, nawiązywały dialog z innymi, że istniało jakieś odnoszenie się pamiętnikarzy do dorobku zastanego, jakaś programowa intertekstualność memuarów. W końcu Europa w rodzinie Marii Czapskiej była „,arystokratyczną” odpowiedzią na ,republikańską" Rodzinnq Europę Miłosza nie tylko na poziomie tytułu...

Należałoby też zinwentaryzować motywacje pamiętnikarzy. Obok motywów deklarowanych przez autorów czy odkrywanych przez emigracyjną krytykę trzeba by starać się dostrzec najgłębsze, a być może - najbardziej rozpowszechnione intencje autorów wspomnień. Dając do druku swoje radiowe pogadanki poświęcone wspominaniu epoki II Rzeczypospolitej Kajetan Morawski wyznawał:

\footnotetext{
${ }^{18}$ S. Wcisło, Przedmowa, [w:] S. Kawczyński, Dzieje jednego życia, Toronto 1984, s. 8.

${ }^{19}$ T. Terlecki, Ignacy Baliński, s. 96.
} 
1918 rok przekreślił naszą rozpacz. Czerpiąc zatem pożywkę z czystego entuzjazmu improwizowaliśmy państwowość niepodległej Polski. Chciałbym, aby przyszli następcy nasi nie wyrzekając się tego entuzjazmu, sięgali także do zapasu naszego doświadczenia ${ }^{20}$.

Wolno przypuszczać, że - przynajmniej w jakiejś części - spisywanie wspomnień uznawano za powinność wynikłą z obowiązku służby idei polskiej niepodległości. Podejrzewam także, że w jakiejś mierze nasilenie literatury wspomnień było wynikiem świadomości pisarzy-emigrantów, że ich książki nie mogą być adresowane do współczesnego im krajowego czytelnika, ale że trzeba nastawiać się na ,późnego wnuka”, kogoś, kto być może jeszcze się nie narodził, a komu przyjdzie żyć w momencie, gdy „zła chwila dziejowa” już przeminie. Temu „,wnukowi” chciano przekazać własne doświadczenia indywidualne i zbiorowe, w ten sposób zapewniając ciągłość polskiej niepodległej myśli.

Oczywiście, propozycje zagadnień badawczych można by tu mnożyć, począwszy od upomnienia się o sporządzenie „mapy” tego nurtu piśmiennictwa emigracyjnego, zajęcie się jego geografią, zestawienie wyczerpującej klasyfikacji tematycznej, itd. Rzecz w tym tylko, by badania takie zostały szerzej podjęte, do czego zachętę chciały dać powyżej spisane uwagi...

\footnotetext{
${ }^{20}$ K. Morawski, Wczoraj. Pogadanki o niepodległym dwudziestoleciu, Londyn 1967, s. 10.
} 